\title{
Absence of Social Amenities: Impeding the Livelihood of Farmers in Matoh Butu
}

\author{
Mbah Alma Andoh ${ }^{*}$, Mobit Joshua Mbah \\ Federation of Environmental and Ecological Diversity for Agricultural Revampment and Human Right, Cameroon
}

Copyright $(2019$ by authors, all rights reserved. Authors agree that this article remains permanently open access under the terms of the Creative Commons Attribution License 4.0 International License

\begin{abstract}
Cameroon's population by January 2017 was estimated to be $24,260,003$ and counting and $45.6 \%$ of this people lived in rural areas. But the lack of social amenities in these areas poses a problem to their health and their general livelihood. Cocoa remains the main cash crop to more than $75 \%$ of the population of Cameroon. It is mainly produced by peasant farmers, who depend mostly on the profit derived from the management of this crop, even though this is a seasonal crop, these farmers. Matoh Butu is a village found in Konye Sub-Division, Meme Division of the South West Region of Cameroon. This study aims at determining the economic situation of the inhabitants of Matoh Butu Village. A field visit was carried out in this village by 6 experts spending two weeks in the village. This was to assess the availability of social amenities; the average quantity of cocoa that they produce; what other crops they produce and if they market these produce; how they manage their farms; how they manage their income and the challenges they face in agriculture. Results show that there is a poor road network leading to the village and to their farms, there is no portable drinking water and there is inadequate health services. An average farmer in the rural area produces 32.3 bags of cocoa yearly but they lack knowledge on how to manage their income since there are no banks in the villages. Only $11.2 \%$ save their money in banks in the cities, $25.4 \%$ save theirs in "njangi" houses while the remaining $64.4 \%$ do not save at all. These make them to mishandle their income and they are forced to borrow chemicals for the next planting season causing the buyers to be the one to determine the price of the cocoa they produce. $84.1 \%$ borrows chemicals from their buyers. The main crop grown there is cocoa. Other food crops like plantain, banana, "okwani Cocoyam", macabo cocoyam, cassava and some vegetables like bitter leaf and ekong-obong are cultivated mainly for home consumption. Only $10 \%$ of the farmers sell their excess. In order to improve on their livelihood, there is need for the construction of roads and bridges to ease transport, portable drinking water and quality healthcare services has to be made available to the people, and they have to be
\end{abstract}

trained on new sources of food to boast their economic status and thought on better agricultural practices.

Keywords Social Amenities, Farmers, Matoh Butu, Poor, Field Survey

\section{Introduction}

Cameroon's population by January 2017 was estimated to be $24,260,003$ and counting and 45.6 of this people live in rural areas. But the lack of social amenities in these areas poses a problem to their health and their general livelihood. Cocoa remains the main cash crop to more than $75 \%$ of the population of Cameroon. It is produced mainly by peasant farmers who even though this is a seasonal crop, these farmers depend mostly on the profit derived from the management of this crop. Matoh Butu is a village found in Konye Sub-Division of the Meme Division of the South West Region of Cameroon. It was founded by a woman called Mrs Bume and the village was then called Matoh Mambuah ("mam" means "little" and "buah" means "rain") thus meaning "little drops of rain". The Bamuteh people from Yaounde were the first people living there. Matoh Butu is boarded to the North by Big Butu Village, to the South by Matoh Efongoh, to the East by Makabe and to the West by Lukando village. Presently, Matoh Butu has ten (10) quarters namely; Tafa, King Street, Water Tank, Fanga, Menge Street, Otibos, Main Street, Otte Street alias Alaska Street, Gundangi 1 and Gundangi 2. Each quarter is head by a Quarter Head who is answerable to the Head council, Mr. John Baliki Tataw who is in turn answerable to the chief, HRH Bokwe Noah Nanje. Matoh Butu is made up of about 2336 inhabitants that come from different tribes and ethnic groups across the country each of which is represented at the council of elders.

Baye and Amungwa [1] mentioned that in 1970s and early 1980s - period of prosperity, the Cameroon government pursued its rural development policies through 
heavily subsidized agricultural projects that were charged with participating in production and marketing, supporting and advising other agricultural institutions and farmers in their areas of operation. Subsequent to initially performing well, these structures, because of mismanagement, became costly and inefficient providers of services to small farmers. Like other public enterprises, they became a haven for political favors. This situation was exacerbated by the economic crisis that began in mid-1980s. The crisis was fuelled, at least in part, by the poor macro-economic performance and the short-term effects of the ensuing policies designed to achieve macro-economic stability.

The harshness of the crisis led to the abandonment of the long-term development planning system pursued since independence in 1961, and the adoption of the IMF/World Bank medium-term structural adjustment programs (SAP) from 1988. The crisis also led to considerable shortfalls in public finances, making it difficult for the government to pursue with vigor its rural development strategy. Even some of the achievements in rural areas in terms of infrastructure deteriorated for lack of maintenance. Many of the rural infrastructures put in place by the state collapsed, thereby aggravating the poverty of the people that benefited from the services provided, Baye and Fambon. [2]

Cameroonian authorities tried to cope with the economic crises by reducing public expenditures - including a $60 \%$ cut in civil services' wages and cuts in producer prices - but the measures did not stimulate growth. The authorities also tried to cope by borrowing to finance budgetary shortfalls in the system. Unfortunately, debt-servicing grew rapidly and started crowding-out investments, Mbanga and Sikod, [7]. By 1993, small-scale coffee and cocoa farmers were some of the most acutely affected and the sub-sectors were liberalized. The provision of public services declined markedly, due to lack of investment and poor performance of state owned enterprises. Government reduced basic health and education funding leading to a major decline in health delivery systems and school enrolment, Khan and Noumba. [6].

Although the 1994 realignment of the XAF helped in the restoration of macro-economic stability and the welfare of some farmers, on the average, it worsened the welfare situation of individuals. These outcomes deepened overall poverty in Cameroon, and rural poverty remained more widespread, deeper and severer than urban poverty, Fambon et al. [4]. The implication is that poverty reduction and sustainable growth cannot be achieved without sufficiently empowering the rural population, DSCN; Njinkeu et al.; World Bank. [3]; [9]; [10].

Research carried out by Francis M. J. [5] in Vekovi (located in the Jakiri Sub-Division, Bui Division, Northwest Province) and Ekona (located in the Muyuka Sub-Division, Fako Division, Southwest Province) shows that in Vekovi, access to the village is relatively poor. It is by dirt road and is done on foot or by old battered vehicles that use five liter plastic containers as their petrol reservoirs attached just next to the engine. The nearest town is $10 \mathrm{~km}$ from the centre of the village, which takes an average of about 45 minutes' drive due to the rocky and undulating nature of the road. Since 1984, access to other towns has been greatly improved due to increased availability of transportation made possible by private investment in clandestine taxis and the seasonal filling of potholes on the road by the community. The enclave nature of the village in terms of road infrastructure and the total absence of radio and TV signals is a vivid indication that the village is yet to take full advantage of information that could help enhance the asset holdings of the local population.

The 1572 households in Vekovi use kerosene lanterns as lambs for lighting in the evening, electricity supply by the National Electricity Corperation (AES SONEL), presently Energy of Cameroon (ENEO), is absent. Generally, about $15 \%$ of households have access to pipe borne water. Majority of the people still drink water from streams and springs that often get completely dry during the dry season.

The role of the churches has been quite significant in the provision of primary education in Vekovi. The Presbyterian, Baptist, Catholic, Muslem vhurches, etc. have been playing a leading role in this domain. Of the 8 primary schools in the village, 7 are denominational schools and another 1 is a government school.

There is no hospital in Vekovi but there are 3 hospitals that are usually accessed by the villagers. One owned by the government with only one medical doctor is $10 \mathrm{~km}$ from the centre of the village and 2 owned by religious denominations are about $24 \mathrm{~km}$ from the village with a wide range of medical doctors and specialists

As for infrastructure, Ekona is a roadside village with a deteriorating highway running through the village. To cover the $7 \mathrm{~km}$ from Ekona to the main administrative office in Muyuka takes about 15 minutes by car or bus. Traffic on the road, in spite its deteriorating condition, is relatively dense. There are farm-to-market roads linking the villages to most of the farms. The CDC constructed some of thee roads for the evacuation of its produce and the Village Development Committee constructed others with donations from some international NGOs and foreign donors. Most of these roads are deteriorating as maintenance is not regular.

Even though, a rural village by Cameroon standards, Ekona has had electricity for a long time (since 1970s). Some $75 \%$ of the households have electricity (Table 6). The village is on the path of the main electricity supply line. The village also has pipe borne water which was installed in 1968 by the CDC. About $25 \%$ of the households have water facilities within their homes. Others use mostly public taps. Other sources of water are springs and streams. The streams serve as sewage facilities for dumping fecal waste and other household garbage. Drainage ditches are also popular toilet facilities. Wastewater is disposed of by throwing outside the house. 
One important way of responding to the plight of the rural poor is to facilitate their access to economic assets that are essential for their survival and well-being. Economic assets in this context include primary assets (natural, physical, human and financial) and secondary assets (formal and informal institutional environments), Nissanke. [8]. This study aims at determining the economic situation of the inhabitants of rural areas with primary data gotten from Matoh Butu Village.

\section{Materials and Methods}

This paper is based on field visits that were carried out in Matoh Butu, Konye Sub-Division in Meme Division in the South West Region of Cameroon with at least 6 expert volunteers, spending two week in the village and interviewing about 100 people. Matoh Butu has ten (10) quarters namely; Tafa, King Street, Water Tank, Fanga, Menge Street, Otibos, Main Street, Otte Street alias Alaska Street, Gundangi 1 and Gundangi 2.

Apart from data about the respondents(Name, Age, Marital status, Occupation, Number of children and name of village) different issues regarding their agricultural systems and village were addressed: number of farms; what they cultivate; size of farm(s); number of children involved in agriculture, if they applied fertilizers and pesticides; how they obtain the chemicals; how they save their income (banks, "njangi" groups, self-savings); how they market their produce(local cocoa vendors, look for markets in cities); infrastructural situation of the village; and the challenges they encounter in the farms and community.

The ages of the respondents ranged from 13 to 80 years; average is 42 years. As for their occupation, the respondents have farming as their occupation (94.9\%) while the remaining $4.1 \%$ do petty jobs (carpentry, seamstresses, hair dressing etc.). A majority of them are married (72.6\%), $15.1 \%$ single, $2.7 \%$ divorced, $8.2 \%$ widows, and $1.4 \%$ widowers. And also, $49.3 \%$ have $0-3$ children, $41.1 \%$ have $4-6$ children and $9.6 \%$ have 7 children and above.

\section{Results and Discussion}

Farmers in rural areas of Cameroon are mainly small scale farmers. Their farms are of varied numbers and sizes which can range between 1 farm of up to 8hectare to 4-8 farms that can be of the same size or more. While some of the farmers own their farms, others take farms on lease and others who do not have enough money to buy their own farmlands, work with the owners of the farm through a system known as "two party" in which the owner of the farm purchases all the farm inputs and they share the profits at the end of the season.

Cocoa is the main crop grown in the area. Other food crops like plantain, banana, "okwani” Cocoyam, macabo cocoyam, cassava and some vegetables like bitter leaf and ekong-obong are cultivated mainly for home consumption. Only $10 \%$ of the farmers sell their excess. Most of the farmers refuse the cultivation of cassava in their farms since it absorbs a lot of water from the soil. Non-timber products like "njangsang", country onion, bush pepper, bush mango serve as alternative sources of income and are therefore termed as "bush-allowance" since they become matured when the cocoa season elapses. Animals like goats, sheep, pigs and domestic birds are reared in the village but only for home consumption. Hunting and fishing are carried out in their forests and rivers respectively. More than $80 \%$ of the inhabitants are willing to accept trainings on the cultivation of new sources of food and new initiatives.

Results show that, an average farmer in the rural areas produces 32.2bags of cocoa in a season, where each bag weighs about $65 \mathrm{Kg}$. But now, they lack the knowledge on how to manage their income since there are no banks in the villages. Most rural people consider their harvesting period as their celebration period as they spend most of their income on drinks and food especially meat and fish. Traders also use this period as an opportunity to come and sell their goods. Only $11.2 \%$ save their money in the cities, $25.4 \%$ save in "njanji" group and $64.4 \%$ do not save at all. These make them to mishandle their income and are forced to borrow chemicals for the next planting season causing the buyers to determine the price of the cocoa they produce. As a result of no saving too, some farmers lease out their farms for large number of years when faced with a misfortune or they have a celebration or ceremony, consequently, they are left to struggle in hunger until these years elapse.

A majority $(84.1 \%)$ of the farmers borrow chemicals from the buyers while the remaining $15.9 \%$ set aside money to buy chemicals for the next season or they buy just what they can afford. 15.3\% keep detailed record about their cocoa farm input, expenses and output while $84.7 \%$ don't. They keep only the records of the amount for the chemicals that they borrowed so that they are not reimbursed in excess during payment. This makes them not to be aware if they are making a lost or gain simply because of unaccountability.

As a result the poor infrastructural nature of the village like many other rural areas, there are no well-equipped schools and trained teachers, $80 \%$ of the farmers send their children to secondary school in the cities. This makes the youths which makes up a higher labor force only available to help their parent during the long holidays (June to August). The farmers are therefore left to hire laborers assist them in carrying out some activities in their farms such as clearing, pruning, spraying and even breaking the cocoa pods to extract the cocoa beans.

The main problem facing rural cocoa farmers is poor roads network linking farm-farm and farm-markets. This makes it difficult for the farmers to look for a better market 
for their produce coupled to the fact that since the farmers find it difficult to transport their farm produce from the farms to the market, their produce are left to get rotten in the farm, some are stolen and others are eaten up by rodents, antelopes and squirrels. There is also a problem of insecurity from the problem of poor road network and this causes some of the farmers $(38.9 \%)$ not to ferment their cocoa for the required period.

Matoh Butu has been unable to have portable drinking water for the past five years. This is because the pipe borne water that was installed in the 1980s has failed because the water can no longer reach the village from the water catchment. The water catchment is found $20 \mathrm{~km}$ from the village settlement and it passes through other villages and the forest. The inhabitants now carry water from their streams which are either far or germ-infested and have a slow flow rate during the dry season. This poses a health problem to the inhabitants hence reducing the labor force.

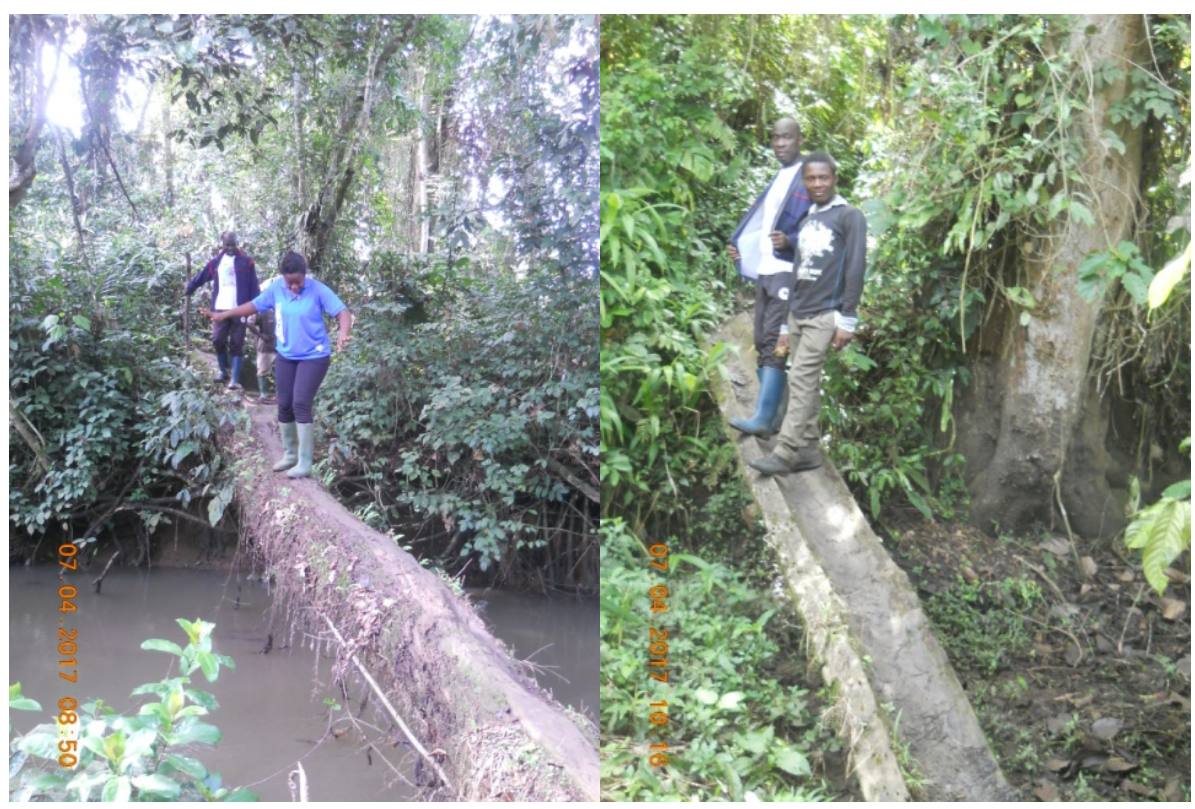

(a)
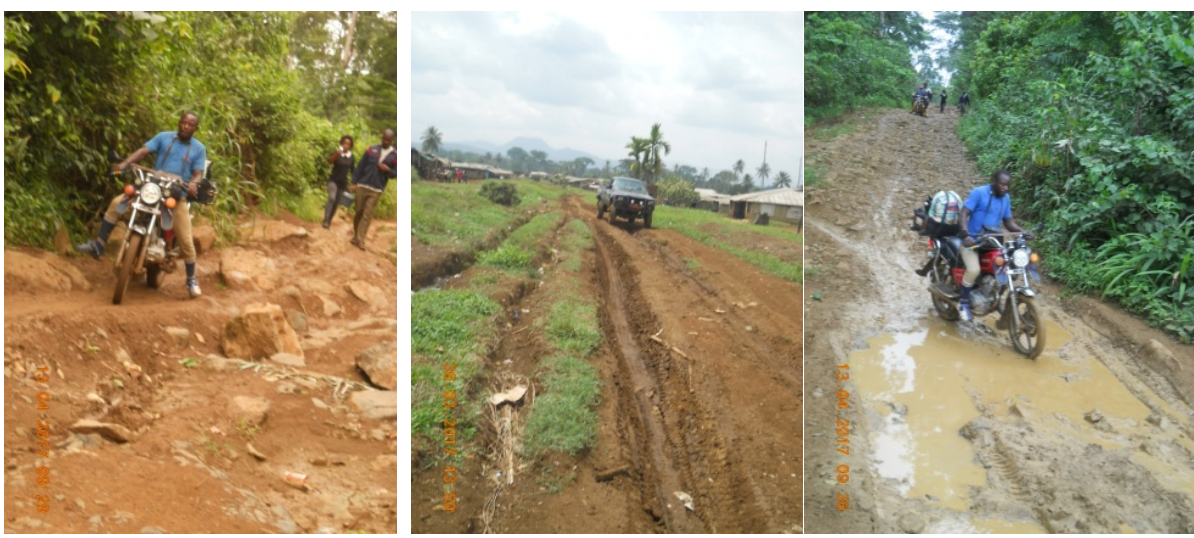

(b)

Figure 1. Images of farm-farm roads (a) and farm-market roads (b) in Matoh Butu 


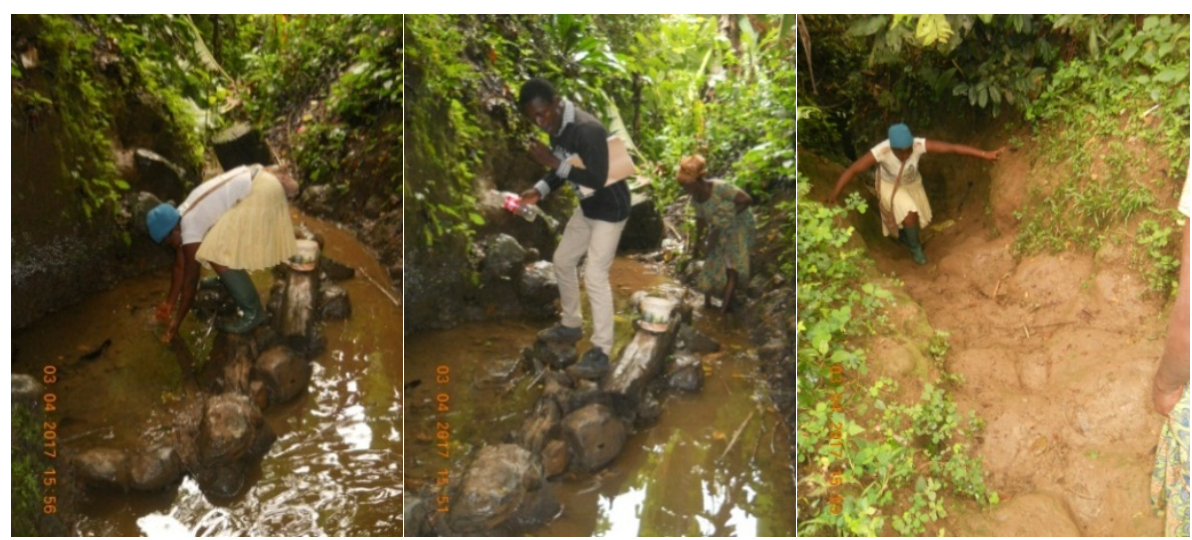

(a)

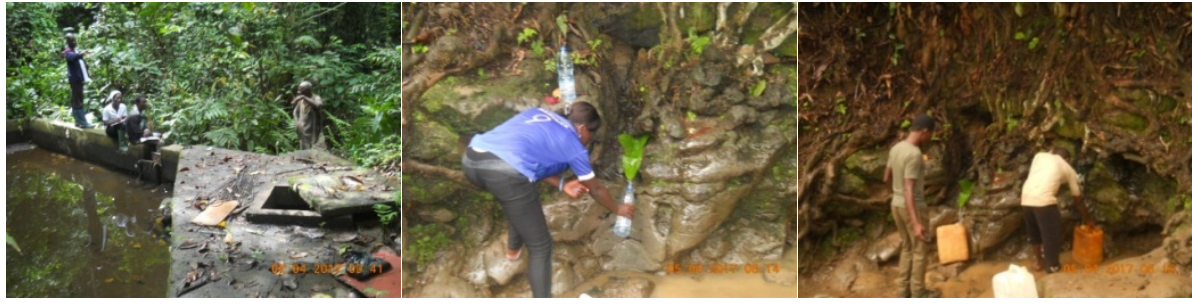

(b)

(c)

Figure 2. Image showing water sources in Matoh Butu; stream (a), water catchment (b) and spring (c)

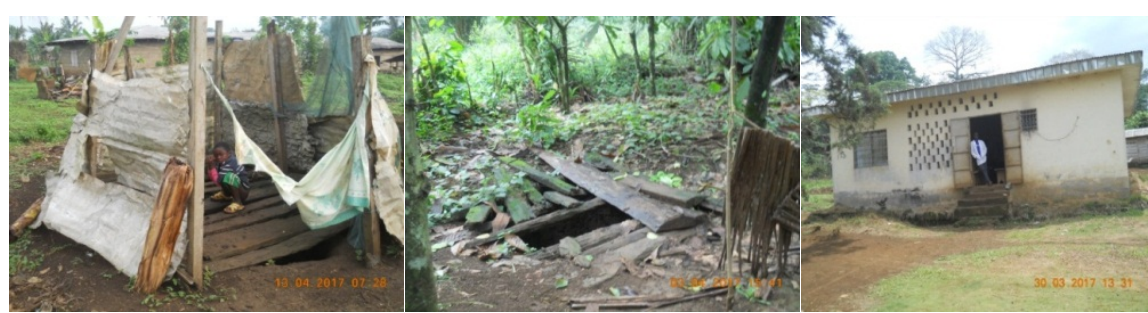

(a)

(b)

Figure 3. Image showing sample toilets (a) and the health centre (b) in Matoh Butu

Matoh Butu has just a health centre which is small (that is it can admit only 8 persons at a time), unequipped and has lack of well-trained personnels. With the prevailing diseases in the villages like malaria, cholera and typhoid from the poor water conditions, waste disposal and toilets, there is a need for a well equipped hospital to meet the needs of the people and for life expectancy.

\section{Conclusions and Recommendations}

The lack of social amenities in Matoh Butu like Vekovi, Ekona [5] andmany other rural areas in Cameroon is and has always been a stumbling block to their sustainable development. Moreover, the lives of the rural people, like that of every citizen, are conditioned by the institutions that facilitate and implement laws and regulations to govern their harmonious existence. In other to improve on their livelihood, there is the need for the construction of roads, bridges, hospitals, toilets where appropriate to ease transport; and quality healthcare services should be made available to the people; they should be trained on new sources of food to boast their economic status and thought on better agricultural practices. To this effect, the government on herself part should spread their tentacles so that these basic amenities reach the rural areas with proper follow-up being made.

There is need for social amenities like electricity, schools and due to the distance from the village to the water catchment $(20 \mathrm{~km})$, it is recommended that bore-holes should be dug in the village vicinity for easy accessibility and maintenance. Linkages with construction companies and donors should be operationalized to establish a better relationship between rural farmers. Linkages have to be made with Micro Finance institutions to ease encourage savings and prevent poor management of income. Nevertheless, this requires the collaboration of the rural people and an improvement in their reliability.

\section{Acknowledgement}

I acknowledge my director, Mr. Tcharbuahbokengo 
NFINN who assisted us financially to carry out our survey. To Moulema Robert, Yangouo Sefoura, Mobit Joshua Mbah, Nkwein Clarisse, Ngepe Elvis who volunteered to carry out the survey. And to the chiefs of Matoh butu, HRH Bokwe Noah Nange who agreed to accommodate us, feed us, secure us and allow us to carry out our survey in their village.

My sincere thanks also, to all the inhabitants of the village who speared time from their busy schedule to answer all our questions.

\section{REFERENCES}

[1] Baye M. F. and Aungwa F. A. (2002); Training in Partnership for development; The Case of Agricultural Family Schools on Rural Cameroon. Pakistan economic and social Review, Volume XL, No. 1, PP. 35-55

[2] Baye M. F. and Fambon S. (2001); The Impact of Micri and Sectoral Policies on the extend of poverty in Cameroon; In Globalisation and Poverty; The Role of Rural Institutions in Cameroon. Final report submitted to FASID, Tokyo, Japan.

[3] DSCN (1996); En quéte Cameroonaise auprés des ménages (ECAM); Volume 2 résultants, Tomes 1-5, Yaoundé.

[4] Fambon S., Amin A. A., Baye M. F., Noumba I., Tambo I. and Tawah R. (2000). Pauvreté et Répartition des Revenus au Cameroun Durant les Années 1990. Cahier de Recharge, No. 01-06 du L'université Laval. http://www.crefa.ccn.ula val.ca/cahier/list01.html

[5] Francis M. B. (2002) ; Rural institutions, Access to primary assets and poverty in Cameroon; Pakistan Economic and Social Review Volume XL, No. 2 (Winter 2002), pp. $121-152$

[6] Khan S. and Noumba I. (2001), Rural Health Care and Educational Services in Cameroon; In Globalisation and Poverty; The Role of Rural Institutions in Cameroon. Background paper submitted to FASID, Tokyo, Japan.

[7] Mbanga G. and Sikod F. (2002), The Impact of Dept and Dept-service Payment on Investments in Cameroon; The final report submitted to EARC, Nairobi, Kenya.

[8] Nissanke M. (2000), Globalization and Poverty; The role of rural Institutions; framework paper for FASID Africa-Asian Comparative Studies presented at the research project on 1-2 December 2000, Nairibi, Kenya.

[9] Njinkeu D., Kobou G. and Noumba I. (1997), Structural Adjustment and poverty in Cameroon; A Labour Market Analysis; final report presented to ICEG Nairobi.

[10] World Bank (1995), Cameroon; Diversity, Growth and Poverty Reduction, Report No. 13167-CM. 